\title{
European Stroke Council
}

\section{Minutes of the Executive Committee Meeting}

April 8, 1999, Venice

The following members were present: Julien Bogousslavsky, Bo Norrving, Gian Luigi Lenzi, Antoni Dàvalos, Werner Hacke, Markku Kaste, Kennedy Lees, Didier Leys. Regrets: José Ferro.

\section{(1) Future Directions for the European Stroke Council (ESC)}

The ESC serves as the coordinating body of several activities: the journal Cerebrovascular Diseases, the European Stroke Initiative, the European Stroke Conferences, the European Stroke Summer Schools, as well as administrative funds. These activities are all functioning well at present and it was felt that there was no reason to interfere more actively from the council. However, it was suggested that a report from a representative of the Programme Committee of the European Stroke Conferences should be given to the ESC executive committee at future meetings.

Several other organisations are active in the stroke field, such as the ENS, EFNS, Mediterranean Stroke Society, and the Scandinavian Stroke Society. A closer collaboration between these societies and the ESC would be desirable, in order to share information on planned activities and to avoid duplications. It was decided to propose to the General Assemby that a) one member of the executive committee should serve as liaison person for the ESC, b) Markku Kaste should be responsible for this task for the next year.

There is also a need for the ESC to become more visible on a national level. To this end it was decided to propose to the General Assembly the formation of an International Advisory Committee to the ESC with 1-2 representatives from each country. The role of the International Advisory Committee would be to propose ideas and topics to the ESC, and to serve in conjunction with e.g. teaching activities. Proposals for national representatives could be submitted to the secretary of the ESC from members within each country, and the elections should take place at the General Assembly.

\section{(2) Report from the Treasurer}

Gian Luigi Lenzi reported that the current balance was CHF 8,350. A surplus from some of the previous European Stroke Conferences is available and used to fund forthcoming conferences.

\section{(3) Report from the Secretary}

Bo Norrving reported that as of April 1999 there were 186 members ( 163 active academic members, 20 corresponding members, and 3 clinical members).

\section{(4) Reports on the Progress of the EUSI}

Markku Kaste, chairman of the EUSI, reported on the current activities of the EUSI. A publication on 'Stroke Prevention by the Practitioner' is published (Cerebrovascular Diseases 9, Supplement 4, 1999), and a CD-ROM on acute management of stroke is under production. An up-dated consensus statement of acute care of stroke will be published in Cerebrovascular Diseases and will be presented at the European Stroke Conference in Vienna next year.

A permanent secretariat has been established and a web site will be in function in the near future. The ESC was given the offer to use the web site for information regarding its activities and previous documents.

There are plans to organize a meeting with Patient Organizations. A meeting planned for the previous year had to be postponed because of lack of funding. Finally, the EUSI provides economical support to the European Stroke Summer School.

\section{(5) Reports on the Progress on the Implementation of the} Helsingborg Declaration

Bo Norrving, chairman of the Steering Group on the Implementation of the Helsingborg Declaration, reported on the current activities. The steering group meets twice yearly. A tool for collection of data on quality of care of stroke is planned, containing a minimum data set and an extended data set of items. The choice of items to be included are currently discussed, and a proposal will be submitted later on to the Executive Committee of the ESC for review. Several centers have expressed an interest in participating in the project.

Guidelines on Management of Stroke, following the domains of the Helsingborg Declaration, are also in the early stage of preparation.

\section{(6) Education Subcommittee}

Werner Hacke reported that the teaching courses of the European Stroke Conference in Venice had been planned by the organizers of the conference with little collaboration with the education subcommittee. This was due to a very tight time schedule for preparation of the programme of the teaching courses, given for the first time at this years' stroke conference. It was suggested that the organizer of the Venice conference should report of the evaluation of the teaching courses to Werner Hacke and Franz Aichner, organizer of the conference next year. Werner Hacke should serve as advisor to the organizer on behalf of the ESC. It was proposed that next years' teaching courses should consist of both basic courses and continuous education.

\section{KARGER \\ Fax + 41613061234 \\ E-Mail karger@karger.ch}

๑) 2000 S. Karger AG, Basel www. karger.com
Accessible online at: www. karger.com/journals/ced 


\section{(7) European Stroke Summer School}

Werner Hacke who organized the Stroke Summer School in Heidelberg in July 1998 reported that the activity was well attended, successfully conducted, and had good spin-off effects (see also separate report in Cerebrovascular Diseases 1999;9:55-56).

The next European Stroke Summer School will be held in Edinburgh in September 1999, organized by Charles Warlow. Two to three of the award winners at this year's stroke conference will be offered free admission to the summer school, and travel support will be offered to two of the poster award winners.

Forthcoming European Stroke Summer Schools will take place in Rome in 2000 (organized by Cesare Fieschi and Danilo Toni), and in Paris in 2001 (organized by Marie-Germaine Bousser and Pierre Amarenco)

\section{(8) Liaison with Other Stroke Societies}

An International Stroke Liaison Committee was formed in conjunction with the Joint Conference on Stroke and Cerebral Circulation in Nashville, Tenn., February 1999, with the aim to facilitate contacts, exchange of information, and harmonisation between the stroke organisations worldwide. It was decided to form six subcommittees: 1) International Trial Collaboration Committee (chair Markku Kaste), 2) Liaison Committee with General Medical Organizations for purposes of Promoting Stroke Programs (chair Lou Caplan), 3) Committee on Post-Graduate Education in Stroke (chair Natan Bornstein), 4) Committee to Coordinate Announcements of International Stroke Meetings (chair Julien Bogousslavsky), 5) Committee on Stroke Guidelines and Consensus Documents (chair Bo Norrving), and 6) Committee on Non-Government Organization/ Patient Advocate (chair Dafydd Thomas). The next meeting will take place during the next Joint Conference on Stroke and Cerebral Circulation in New Orleans next year.

\section{(9) Stroke Subspeciality}

Kennedy Lees raised the issue on formation of a specific subspeciality of stroke. The proposal is based on the notion that today in most countries a major proportion of patients with stroke are managed by physicians who do not possess adequate skills in stroke. An educational programme for a stroke specialist should consist of training in neurology, cardiology, general medicine, and rehabilitation. Similar discussions are currently taking place in the United States. The European Commission has declared that subspecialities should be similar across the member states.

It was decided to propose to the General Assemby that Kennedy Lees should prepare a proposal to be submitted to the members of the executiv committee of the ESC for review and comments. Subsequent actions will be discussed within the committee.

\section{(10) Other Matters}

Werner Hacke reported that an application had been sent to the regulatory authorities in Germany for a restricted approval within the European Community of the use of rt-PA in acute brain infarction. Werner Hacke suggested that an official endorsement from the ESC on the restricted use of rt-PA should be considered. It was decided to propose to the General Assembly that Werner Hacke and Kennedy Lees should consider the preparation of a letter on this issue on behalf of the ESC.

Bo Norrving, Secretary of the ESC Julien Bogousslavsky, Chairman of the ESC

\section{Minutes of the General Assembly}

April 9, 1999, Venice

\section{(1) Chair}

Julien Bogousslavsky, chairman of the European Stroke Council (ESC) had to leave regrets for the General Assembly. The Assembly was therefore co-chaired by Markku Kaste and Bo Norrving.

\section{(2) International Advisory Committee of the ESC}

The General Assembly adopted the proposal to form an International Advisory Committee to the ESC, and the proposed election procedure. Invitation to suggest national candidates should be announced before the next European Stroke Conference in Vienna in 2000, and the aim should be to have the first elections at the General Assembly during the conference.

\section{(3) Reports from the Secretary and Treasurer}

See paragraphs 2 and 3 of executive committee minutes.

(4) Reports on the Progress of the EUSI, the Implementation of the Helsingborg Declaration, the Educational Subcommittee, and

the European Summer School

See paragraphs 4 to 7 of executive committee minutes. The preliminary versions of the minimum and extended data sets on quality issues in stroke management was presented by Martien Limburg, chairman of the working group on quality assessment of the Helsingborg Declaration Steering Committee.

\section{(5) Stroke Subspeciality}

The proposal to form a subspeciality in stroke was presented by Kennedy Lees. The General Assembly adopted the proposal. Kennedy Lees was given the task to formulate an education plan to present to the ESC for comments.

\section{(6) ESC Support for Registration of rt-PA}

The proposal to consider submission of a statement from the ESC, supporting a restricted approval of rt-PA in acute brain infarction, was endorsed by the General Assembly.

Bo Norrving, Markku Kaste Co-chairmen of the General Assembly

\section{Members of the Executive Committee of the European Stroke Council}

Duration in office (end of term, year):

Julien Bogousslavsky: 2002 (chairman 2000), Bo Norrving: 2000, Gian Luigi Lenzi: 2001, Antoni Dàvalos: 2002, José Ferro: 2000, Werner Hacke: 2000, Markku Kaste: 2000, Kennedy Lees: 2002, Didier Leys: 2002

\section{Announcements}

1. Four members will be elected to the Executive Committee during the forthcoming European Stroke Conference in Vienna. Nominations with letters of support should be directed to the secretary Bo Norrving, MD.

2. Candidates for the International Advisory Committee should also be announced to the secretary for elections during the European Stroke Conference in Vienna. 